\title{
Effect of Varied Irrigation Scheduling with Levels and Times of Nitrogen Application on Yield and Water Use Efficiency of Aerobic Rice
}

\author{
Murugesan Mohana Keerthi ${ }^{*}$, Rajagopalan Babu' ${ }^{2}$, Nagalingam Somasundaram Venkataraman1, \\ Elangovan Subramanian², Karunanandham Kumutha ${ }^{3}$
}

${ }^{1}$ Department of Agronomy, Agricultural College and Research Institute, Tamil Nadu Agricultural University, Madurai, India ${ }^{2}$ Department of Farm Management, Agricultural College and Research Institute, Tamil Nadu Agricultural University, Madurai, India

${ }^{3}$ Department of Agricultural Microbiology, Agricultural College and Research Institute, Tamil Nadu Agricultural University, Madurai, India

Email: *mmkeerthi@gmail.com

How to cite this paper: Keerthi, M.M., Babu, R., Venkataraman, N.S., Subramanian, E. and Kumutha, K. (2018) Effect of Varied Irrigation Scheduling with Levels and Times of Nitrogen Application on Yield and Water Use Efficiency of Aerobic Rice. American Journal of Plant Sciences, 9 , 2287-2296.

https://doi.org/10.4236/ajps.2018.911165

Received: October 8, 2018

Accepted: October 26, 2018

Published: October 29, 2018

Copyright $\odot 2018$ by authors and Scientific Research Publishing Inc. This work is licensed under the Creative Commons Attribution International License (CC BY 4.0).

http://creativecommons.org/licenses/by/4.0/ (c) () Open Access

\begin{abstract}
More rice needs to be produced with lesser water to feed the increasing human population. Judicious water management practices and appropriate water saving technologies in rice cultivation are in need in the coming decades. Aerobic rice is one of water saving method of rice cultivation. The field experiment was conducted during Summer season of February 2018 to May 2018 at Tamil Nadu Agricultural University, Agricultural College and Research Institute, Madurai, to find out the effect of irrigation schedules with varied doses and time of nitrogen application on yield of aerobic rice. Irrigation scheduling of IW/CPE (Irrigation Water/Cumulative Pan Evaporation) 1.0 up to panicle initiation stage and thereafter IW/CPE 1.2 up to dough stage recorded higher yield attributes viz., number of panicles hill ${ }^{-1}$ (9.1), number of filled grains panicle ${ }^{-1}(87.9)$, test weight $(15.3 \mathrm{~g})$, grain yield $\left(4462 \mathrm{~kg} \cdot \mathrm{ha}^{-1}\right)$, straw yield $\left(5977 \mathrm{~kg} \cdot \mathrm{ha}^{-1}\right)$. However, the highest water use efficiency (6.8 $\mathrm{kg} \cdot \mathrm{ha}^{-1} \cdot \mathrm{mm}^{-1}$ ) was recorded in the treatment of IW/CPE 1.0 throughout the crop growth period. Lower yield attributes, yield and water use efficiency were recorded with irrigation scheduling of IW/CPE 0.8 throughout the growth stage. Application of nitrogen at $150 \mathrm{~kg} \cdot \mathrm{ha}^{-1}$ in 5 equal splits at 20,35, 50, 65 and 80 DAS (Days after sowing) recorded higher yield attributes viz., number of panicles hill ${ }^{-1}(9.3)$, number of filled grains panicle ${ }^{-1}$ (90.5), test weight $(15.4 \mathrm{~g})$, grain yield $\left(4746 \mathrm{~kg} \cdot \mathrm{ha}^{-1}\right)$, straw yield $\left(6258 \mathrm{~kg} \cdot \mathrm{ha}^{-1}\right)$ and WUE $\left(7.5 \mathrm{~kg} \cdot \mathrm{ha}^{-1} \cdot \mathrm{mm}^{-1}\right)$. Application of nitrogen $100 \mathrm{~kg} \cdot \mathrm{ha}^{-1}$ in 4 equal splits at 20,40,60 and 80 DAS recorded lower yield attributes, yield and water use efficiency. The interaction effect between irrigation scheduling and nitrogen
\end{abstract}


management on yield was significant. The combination of IW/CPE 1.0 up to panicle initiation stage and thereafter IW/CPE 1.2 up to dough stage along with application of nitrogen at $150 \mathrm{~kg} \cdot \mathrm{ha}^{-1}$ in 5 equal splits at $20,35,50,65$ and 80 DAS significantly produced higher number of panicles hill ${ }^{-1}$ (10.7), grain yield of $5419 \mathrm{~kg} \cdot \mathrm{ha}^{-1}$ and straw yield of $6906 \mathrm{~kg} \cdot \mathrm{ha}^{-1}$. However, IW/CPE 1.0 throughout the growth period along with application of nitrogen at 150 $\mathrm{kg} \cdot \mathrm{ha}^{-1}$ in 5 equal splits at 20,35, 50, 65 and 80 DAS registered the highest water use efficiency $\left(8.4 \mathrm{~kg} \cdot \mathrm{ha}^{-1} \cdot \mathrm{mm}^{-1}\right)$ in aerobic rice.

\section{Keywords}

Aerobic Rice, Irrigation, IW/CPE, Nitrogen, Yield, Water Use Efficiency

\section{Introduction}

Rice is the most widely consumed cereal grain on earth and is the staple food for over half of the world's population. Asia's food security depends mainly on irrigated lowland rice fields, which produce three-quarters of all rice harvested [1]. At present the productivity of Asia's irrigated rice systems is increasingly threatened by water scarcity. In the next 25 years, 15 to 20 million hectares of lowland rice in Asia are projected to suffer from water scarcity [2]. Hence, shifting gradually from traditional rice production system to growing rice aerobically, especially in water scarce irrigated lowlands, can mitigate the water deficient condition. Cultivation of rice by method of aerobic will save water as it is grown under non flooded conditions in non-puddled, unsaturated soil. Aerobic rice cultivation not only reduces the water requirement but also sustains the rice productivity. However, the major constraints which limit the yield of aerobic rice is high weed infestations [3], lesser nutrient availability and micro-nutrient deficiencies [4] [5]; and nematode infestations [6].

Scheduling of irrigation in irrigated dry aerobic rice plays a major role in obtaining higher yields as well as higher water productivity [7]. Effective tillers and grain yield of rice increased with the decrease in irrigation interval up to 5 days and any further decrease in irrigation interval did not prove beneficial [8] [9]. Nitrogen is the important and major nutrient in rice crop. Its efficiency can be improved by scheduling of irrigation and weed management. Optimum timing of nitrogen application coupled with irrigation scheduling would enhance the availability of nitrogen to the crops and increased the grain yield of rice in aerobic rice cultivation [10]. The grain yield, yield attributes, grain quality parameters and soil microbial activities were also influenced by split application of nitrogen [11]. Increased yield due to application of nitrogen with presences of optimum soil moisture in the root zone [12]. With these perspectives experiment was conducted to study the effect of irrigation scheduling and nitrogen doses along with split application influence the yield attributes and yield of aerobic rice. 


\section{Materials and Methods}

\subsection{Experimental Site and Design}

To study the influence of irrigation scheduling and nitrogen management on performance of rice in aerobic condition, field experiment was conducted during summer 2018 at Agricultural College and Research Institute, Madurai $\left(9^{\circ} 54^{\prime} \mathrm{N}\right.$ latitude and $78^{\circ} 54^{\prime} \mathrm{E}$ longitude), Tamil Nadu, India. The field experiment was laid out in a split plot design. The spacing of rice was $20 \times 10 \mathrm{~cm}$. The soil of experimental site was sandy clay loam (pH-7.04, Ec-0.33 dS m ${ }^{-1}$ and Organic carbon- 0.42 per cent). Rice variety ADT (R) 45 was used for the field experiment. Irrigation water was measured through Parshall flume in open irrigation channel.

\subsection{Treatment Details}

Main plot: Irrigation scheduling

$\mathrm{I}_{1}$-IW/CPE 0.8 throughout the growth stage

$\mathrm{I}_{2}-\mathrm{IW} / \mathrm{CPE} 0.8$ up to panicle initiation stage and thereafter IW/CPE 1.0 up to dough stage

$\mathrm{I}_{3}-\mathrm{IW} / \mathrm{CPE} 0.8$ up to panicle initiation stage and thereafter IW/CPE 1.2 up to dough stage

$\mathrm{I}_{4}$-IW/CPE 1.0 throughout the growth stage

$\mathrm{I}_{5}-\mathrm{IW} / \mathrm{CPE} 1.0$ up to panicle initiation stage and thereafter IW/CPE 1.2 up to dough stage

(Note: IW/ CPE-Irrigation Water/Cumulative Pan Evaporation)

\section{Sub plot: Nitrogen management}

$\mathrm{N}_{1}-100 \mathrm{~kg} \mathrm{~N}: 4$ equal splits at 20, 40, 60 and 80 DAS

$\mathrm{N}_{2}-100 \mathrm{~kg} \mathrm{~N}: 5$ equal splits at 20, 35, 50, 65 and 80 DAS

$\mathrm{N}_{3}-125 \mathrm{~kg} \mathrm{~N}: 4$ equal splits at 20,40,60 and 80 DAS

$\mathrm{N}_{4}-125 \mathrm{~kg} \mathrm{~N}: 5$ equal splits at 20,35, 50, 65 and 80 DAS

$\mathrm{N}_{5}-150 \mathrm{~kg} \mathrm{~N}: 4$ equal splits at 20, 40, 60 and 80 DAS

$\mathrm{N}_{6}-150 \mathrm{~kg} \mathrm{~N}: 5$ equal splits at 20,35, 50, 65 and 80 DAS

(Note: N-Nitrogen, DAS-Days after sowing)

\subsection{Statistical Analysis}

The observed data on the crop were statistically analysed by following procedure for split plot design [13]. Analysis was done with the help of "AGRIS" software. Critical differences (C.D) were worked out at five per cent probability level to check the significance of treatment's mean. The treatment differences that were non-significant at five per cent were denoted as NS.

\subsection{Observations}

\subsubsection{Number of Panicles Hill-1}

The numbers of panicle hill ${ }^{-1}$ were counted from five randomly tagged plants in each plot. 


\subsubsection{Number of Filled Grains Panicle ${ }^{-1}$}

The total numbers of filled grains in randomly selected panicles from the tagged plants were counted and the mean was expressed as numbers panicle ${ }^{-1}$.

\subsubsection{Test Grain Weight}

From each plot, one thousand filled grains were collected at harvest. After drying to the moisture content of 14 per cent, the grains were weighed in an electronic balance and expressed in gram (g).

\subsubsection{Grain Yield}

The harvested plants from net plot area $\left(15.1 \mathrm{~m}^{2}\right)$ were threshed manually from each plot and the harvested grain was separately sun dried, cleaned and weighed. Grain yield was computed at 14 per cent moisture and expressed in $\mathrm{kg} \cdot \mathrm{ha}^{-1}$

\subsubsection{Straw Yield}

The straw obtained from each net plot area $\left(15.1 \mathrm{~m}^{2}\right)$ was sun dried, weighed and expressed in $\mathrm{kg} \cdot \mathrm{ha}^{-1}$

\subsubsection{Water Use Efficiency (WUE)}

Field water use efficiency (WUE) was computed using the equation suggested by Viets [14].

$$
W U E=\frac{\text { Grain yield }\left(\mathrm{kg} \cdot \mathrm{ha}^{-1}\right)}{\text { Total water used to produce the yield }(\mathrm{mm})}
$$

\section{Results and Discussion}

\subsection{Yield Attributes}

Irrigation scheduling of IW/CPE of 1.0 up to panicle initiation stage and there after IW/CPE of 1.2 up to dough stage $\left(\mathrm{I}_{5}\right)$ recorded significantly higher yield attributes viz., number of panicles hill ${ }^{-1}(9.1)$, number of filled grains panicle ${ }^{-1}$ (87.9) and test weight (15.3 g) (Table 1). However, irrigation scheduling of IW/CPE 1.0 throughout the growth stage $\left(\mathrm{I}_{4}\right)$ did not differ significant from the above treatment. This might due to increase leaf area; leading to higher photosynthates and accumulation of more assimilates which led to increased sink size [15]. Lower yield attributes was recorded with irrigation scheduling of IW/CPE 0.8 throughout the growth stage $\left(\mathrm{I}_{1}\right)$. Severe water stress conditions after imposition of irrigation schedules resulted in lower yield parameters and yield due to unfavourable conditions generated with the drying of rhizosphere as earlier reported by Rahman et al. [16]. Parihar [17] also observed that decreasing yield attributes with increasing irrigation intervals.

Application of nitrogen at $150 \mathrm{~kg} \cdot \mathrm{ha}^{-1}$ in 5 equal splits at 20, 35, 50, 65 and 80 DAS $\left(\mathrm{N}_{6}\right)$ recorded the highest number of panicles hill ${ }^{-1}(9.3)$, number of filled grains panicle $^{-1}$ (90.5) and test weight (15.4 g) (Table 1). The supply of $150 \mathrm{~kg} \mathrm{~N}$ $\mathrm{ha}^{-1}$ was found significant in favouring structural and functional activities of the crop in aerobic condition [18]. The extended split application of nitrogen up to 
80 DAS helped to meet the crop requirement and resulted not only in reducing the loss of nitrogen but also increased the nitrogen absorption, consequently better utilization of applied nitrogen resulting in higher yield attributes. This same phenomenon was reported earlier by Devi and Suamthi [19] in aerobic rice.

\subsection{Yield}

The yield of aerobic rice was higher with irrigation scheduling of IW/CPE of 1.0 up to panicle initiation stage and thereafter IW/CPE of 1.2 up to dough stage $\left(I_{5}\right)$ with the highest grain yield of $4462 \mathrm{~kg} \cdot \mathrm{ha}^{-1}$ and straw yield of $5977 \mathrm{~kg} \cdot \mathrm{ha}^{-1}$ (Table 1). This increased yield was due to better availability of moisture, which in turn leads to efficient physiological activity. However, irrigation scheduling of IW/CPE 1.0 throughout the growth stage $\left(\mathrm{I}_{4}\right)$ did not differ significant from the above treatment in yield. The results of the experiment are in accordance with the results of Belder et al. [20] and Shekara et al. [21]. They explained that efficient translocation of photosynthates from source to sink might be responsible for the increased yield. Lowest grain and straw yield were associated with irrigation scheduling of IW/CPE ratio of 0.8 throughout the growth stage $\left(\mathrm{I}_{1}\right)$. The decreased yield was mainly due to severe moisture stress in the soil which led to reduced growth and physiological activities. Further it also interferes with the pollination, fertilization and grain filling as reported by Rao et al. [7].

Application of nitrogen at $150 \mathrm{~kg} \cdot \mathrm{ha}^{-1}$ in 5 equal splits at 20,35, 50, 65 and 80 DAS $\left(\mathrm{N}_{6}\right)$ recorded higher grain yield of $4746 \mathrm{~kg} \cdot \mathrm{ha}^{-1}$ (Table 1) and straw yield of $6258 \mathrm{~kg} \cdot \mathrm{ha}^{-1}$ (Table 2). Application of $150 \mathrm{~kg}$ of nitrogen in five equal splits enhanced stature of growth and yield attributes, forming large sink size coupled with efficient translocation of photosynthates from source to sink, which would have registered in more of filled grains and there by increased the grain and straw yield [22] and [23]. The increased straw yield was due to higher uptake of nitrogen and resulted in the vigorous vegetative growth of rice, Mandal et al. [12] also reported such results. The split application of nitrogen enhanced the utilization of applied nitrogen and minimized the loss of nitrogen through leaching. This result was also conformity with the findings of Balasubramanian [24]. Application of nitrogen at $100 \mathrm{~kg} \cdot \mathrm{ha}^{-1}$ in four equal splits at 20, 40, 60 and 80 DAS $\left(\mathrm{N}_{1}\right)$ significantly resulted in lower grain and straw yield. This was due to lesser nitrogen availability under aerobic condition which resulted in reduced yield.

\subsection{Water Use Efficiency (WUE)}

The highest water use efficiency of $6.8 \mathrm{~kg} \cdot \mathrm{ha}^{-1} \cdot \mathrm{mm}^{-1}$ was recorded with the irrigation scheduling IW/CPE of 1.0 throughout the growth stage $\left(\mathrm{I}_{4}\right)$. This might due to increased grain yield and reduced water consumption when compared to the other irrigation scheduling treatments [25]. Application of nitrogen at 150 $\mathrm{kg} \cdot \mathrm{ha}^{-1}$ in 5 equal splits at $20,35,50,65$ and 80 DAS $\left(\mathrm{N}_{6}\right)$ registered the highest 
WUE of $7.5 \mathrm{~kg} \cdot \mathrm{ha}^{-1} \cdot \mathrm{mm}^{-1}$ (Table 1 ). Increase in nitrogen levels resulted in higher WUE due to increased yield under higher nitrogen level [26].

\subsection{Interaction Effect (Irrigation $x$ Nitrogen)}

The interaction effect between irrigation scheduling and nitrogen management were significant (Table 2). The combination of IW/CPE of 1.0 up to panicle initiation stage and thereafter IW/CPE of 1.2 up to dough stage $\left(\mathrm{I}_{5}\right)$ along with application of nitrogen at $150 \mathrm{~kg} \cdot \mathrm{ha}^{-1}$ in 5 equal splits at 20, 35, 50, 65 and 80 DAS $\left(\mathrm{I}_{5} \mathrm{~N}_{6}\right)$ significantly produced higher number of panicles hill ${ }^{-1}(10.7)$, grain yield of $5419 \mathrm{~kg} \cdot \mathrm{ha}^{-1}$ and straw yield of $6906 \mathrm{~kg} \cdot \mathrm{ha}^{-1}$. However, IW/CPE 1.0 throughout the growth stage along with application of nitrogen at $150 \mathrm{~kg} \cdot \mathrm{ha}^{-1}$ in 5 equal splits at 20,35, 50, 65 and 80 DAS $\left(\mathrm{I}_{4} \mathrm{~N}_{6}\right)$ recorded higher water use efficiency of $8.4 \mathrm{~kg} \cdot \mathrm{ha}^{-1} \cdot \mathrm{mm}^{-1}$. This was due to the combined effect of soil moisture availability, nitrogen availability and enhanced uptake of nutrients throughout the growth period as reported earlier by Mandal et al. [12] and Reddy et al. [27].

Table 1. Influence of irrigation scheduling and nitrogen levels with split application on yield attributes, yield and water use efficiency of aerobic rice.

\begin{tabular}{|c|c|c|c|c|c|c|}
\hline Treatments & $\begin{array}{c}\text { Number of } \\
\text { panicles hill-1 }\end{array}$ & $\begin{array}{l}\text { Number of filled } \\
\text { grains panicle }^{-1}\end{array}$ & $\begin{array}{l}\text { Test weight } \\
\text { (g) }\end{array}$ & $\begin{array}{c}\text { Grain yield } \\
\left(\mathrm{kg} \cdot \mathrm{ha}^{-1}\right)\end{array}$ & $\begin{array}{l}\text { Straw yield } \\
\left(\mathrm{kg} \cdot \mathrm{ha}^{-1}\right)\end{array}$ & $\begin{array}{c}\text { Water Use } \\
\text { Efficiency } \\
\left(\mathrm{kg} \cdot \mathrm{ha}^{-1} \cdot \mathrm{mm}^{-1}\right)\end{array}$ \\
\hline \multicolumn{7}{|c|}{ Irrigation Scheduling } \\
\hline $\mathrm{I}_{1}$ & 6.6 & 77.6 & 14.0 & 3405 & 4665 & 5.8 \\
\hline $\mathrm{I}_{2}$ & 7.3 & 81.2 & 14.4 & 3678 & 5256 & 5.8 \\
\hline $\mathrm{I}_{3}$ & 8.0 & 82.9 & 14.9 & 3906 & 5459 & 6.2 \\
\hline $\mathrm{I}_{4}$ & 8.7 & 84.8 & 15.1 & 4278 & 5745 & 6.8 \\
\hline $\mathrm{I}_{5}$ & 9.1 & 87.9 & 15.3 & 4462 & 5977 & 6.5 \\
\hline S.Ed. & 0.16 & 1.57 & 0.33 & 70 & 91 & * \\
\hline C.D. (0.05) & 0.37 & 3.62 & 0.77 & 161 & 211 & * \\
\hline \multicolumn{7}{|c|}{ Nitrogen Management } \\
\hline $\mathrm{N}_{1}$ & 6.7 & 76.8 & 14.1 & 3238 & 4705 & 5.1 \\
\hline $\mathrm{N}_{2}$ & 7.3 & 78.8 & 14.4 & 3583 & 5014 & 5.7 \\
\hline $\mathrm{N}_{3}$ & 7.7 & 81.0 & 14.6 & 3735 & 5203 & 5.9 \\
\hline $\mathrm{N}_{4}$ & 8.5 & 86.8 & 15.1 & 4288 & 5754 & 6.7 \\
\hline $\mathrm{N}_{5}$ & 8.2 & 83.1 & 15.0 & 4085 & 5589 & 6.4 \\
\hline $\mathrm{N}_{6}$ & 9.3 & 90.5 & 15.4 & 4746 & 6258 & 7.5 \\
\hline S.Ed. & 0.15 & 1.68 & 0.36 & 76 & 102 & * \\
\hline C.D. (0.05) & 0.32 & 3.66 & 0.79 & 152 & 221 & * \\
\hline
\end{tabular}

${ }^{*}$ Data not statistically analyzed. 
Table 2. Interaction ( $\mathrm{x} \mathrm{N}$ ) effects of irrigation scheduling and nitrogen levels with split application on yield attributes, yield and water use efficiency of aerobic rice.

\begin{tabular}{|c|c|c|c|c|c|c|}
\hline Treatments & $\begin{array}{l}\text { Number of panicles } \\
\text { hill }^{-1}\end{array}$ & $\begin{array}{l}\text { Number of filled } \\
\text { grains panicle }^{-1}\end{array}$ & $\begin{array}{c}\text { Test weight } \\
\text { (g) }\end{array}$ & $\begin{array}{l}\text { Grain yield } \\
\left(\mathrm{kg} \cdot \mathrm{ha}^{-1}\right)\end{array}$ & $\begin{array}{l}\text { Straw yield } \\
\left(\mathrm{kg} \cdot \mathrm{ha}^{-1}\right)\end{array}$ & $\begin{array}{c}\text { Water Use } \\
\text { Efficiency } \\
\left(\mathrm{kg} \cdot \mathrm{ha}^{-1} \cdot \mathrm{mm}^{-1}\right)\end{array}$ \\
\hline $\mathrm{I}_{1} \mathrm{~N}_{1}$ & 5.8 & 72.3 & 13.4 & 2873 & 4028 & 4.9 \\
\hline $\mathrm{I}_{1} \mathrm{~N}_{2}$ & 6.3 & 73.7 & 13.5 & 3243 & 4296 & 5.6 \\
\hline $\mathrm{I}_{1} \mathrm{~N}_{3}$ & 6.5 & 75.5 & 13.9 & 3321 & 4475 & 5.7 \\
\hline $\mathrm{I}_{1} \mathrm{~N}_{4}$ & 7.0 & 80.6 & 14.4 & 3624 & 4904 & 6.2 \\
\hline $\mathrm{I}_{1} \mathrm{~N}_{5}$ & 6.9 & 79.1 & 14.2 & 3443 & 4795 & 5.9 \\
\hline $\mathrm{I}_{1} \mathrm{~N}_{6}$ & 7.2 & 84.3 & 14.8 & 3925 & 5490 & 6.7 \\
\hline $\mathrm{I}_{2} \mathrm{~N}_{1}$ & 6.1 & 75.7 & 13.8 & 3162 & 4637 & 5.0 \\
\hline $\mathrm{I}_{2} \mathrm{~N}_{2}$ & 6.7 & 77.4 & 14.1 & 3437 & 4922 & 5.4 \\
\hline $\mathrm{I}_{2} \mathrm{~N}_{3}$ & 7.1 & 79.8 & 14.3 & 3591 & 5137 & 5.7 \\
\hline $\mathrm{I}_{2} \mathrm{~N}_{4}$ & 8.0 & 85.5 & 14.8 & 3891 & 5569 & 6.2 \\
\hline $\mathrm{I}_{2} \mathrm{~N}_{5}$ & 7.0 & 81.0 & 14.4 & 3690 & 5372 & 5.8 \\
\hline $\mathrm{I}_{2} \mathrm{~N}_{6}$ & 8.7 & 87.6 & 15.2 & 4300 & 5898 & 6.8 \\
\hline $\mathrm{I}_{3} \mathrm{~N}_{1}$ & 6.6 & 76.4 & 14.1 & 3207 & 4785 & 5.1 \\
\hline $\mathrm{I}_{3} \mathrm{~N}_{2}$ & 7.1 & 79.8 & 14.5 & 3589 & 5116 & 5.7 \\
\hline $\mathrm{I}_{3} \mathrm{~N}_{3}$ & 7.8 & 81.5 & 14.8 & 3725 & 5229 & 5.9 \\
\hline $\mathrm{I}_{3} \mathrm{~N}_{4}$ & 8.5 & 86.3 & 15.4 & 4196 & 5724 & 6.6 \\
\hline $\mathrm{I}_{3} \mathrm{~N}_{5}$ & 8.6 & 82.8 & 15.1 & 3926 & 5688 & 6.2 \\
\hline $\mathrm{I}_{3} \mathrm{~N}_{6}$ & 9.5 & 90.5 & 15.6 & 4792 & 6213 & 7.6 \\
\hline $\mathrm{I}_{4} \mathrm{~N}_{1}$ & 7.3 & 78.6 & 14.4 & 3401 & 4970 & 5.4 \\
\hline $\mathrm{I}_{4} \mathrm{~N}_{2}$ & 8.0 & 80.0 & 14.6 & 3705 & 5268 & 5.9 \\
\hline $\mathrm{I}_{4} \mathrm{~N}_{3}$ & 8.5 & 83.1 & 15.2 & 3956 & 5346 & 6.3 \\
\hline $\mathrm{I}_{4} \mathrm{~N}_{4}$ & 9.3 & 89.3 & 15.6 & 4757 & 6213 & 7.5 \\
\hline $\mathrm{I}_{4} \mathrm{~N}_{5}$ & 9.0 & 84.0 & 15.3 & 4553 & 5892 & 7.2 \\
\hline $\mathrm{I}_{4} \mathrm{~N}_{6}$ & 10.3 & 93.8 & 15.7 & 5296 & 6783 & 8.4 \\
\hline $\mathrm{I}_{5} \mathrm{~N}_{1}$ & 7.8 & 81.2 & 14.6 & 3550 & 5106 & 5.2 \\
\hline $\mathrm{I}_{5} \mathrm{~N}_{2}$ & 8.3 & 83.0 & 15.1 & 3941 & 5470 & 5.7 \\
\hline $\mathrm{I}_{5} \mathrm{~N}_{3}$ & 8.6 & 85.3 & 15.0 & 4080 & 5827 & 5.9 \\
\hline $\mathrm{I}_{5} \mathrm{~N}_{4}$ & 9.9 & 92.5 & 15.2 & 4971 & 6359 & 7.2 \\
\hline $\mathrm{I}_{5} \mathrm{~N}_{5}$ & 9.4 & 88.7 & 15.8 & 4812 & 6197 & 7.0 \\
\hline $\mathrm{I}_{5} \mathrm{~N}_{6}$ & 10.7 & 96.4 & 15.9 & 5419 & 6906 & 7.9 \\
\hline S.Ed. & 0.34 & 3.82 & 0.82 & 170 & 231 & * \\
\hline C.D. $(0.05)$ & 0.70 & NS & NS & 349 & 477 & * \\
\hline
\end{tabular}

${ }^{*}$ Data not statistically analyzed. 


\section{Conclusion}

From the present investigation, it can be concluded that irrigation scheduling of IW/CPE of 1.0 up to panicle initiation stage and thereafter IW/CPE of 1.2 up to dough stage along with application of nitrogen at $150 \mathrm{~kg} \cdot \mathrm{ha}^{-1}$ in 5 equal splits was found to be the better practice for obtaining higher yield attribute and yield. Irrigation at IW/CPE 1.0 throughout the growth stage along with application of nitrogen at $150 \mathrm{~kg} \cdot \mathrm{ha}^{-1}$ in 5 equal splits at 20,35, 50, 65 and 80 DAS was recorded the highest water use efficiency in aerobic rice. Hence, it can be adopted as a better management practices for water scarce areas instead of continuous flooding.

\section{Future Thrust}

Research is needed for screening of drought tolerant cultivars with high yielding characters and appropriate weed management practices for aerobic culture. Also studies are required for developing a new ideotype for aerobic rice with better root characters to survive under moisture stress condition.

\section{Conflicts of Interest}

The authors declare no conflicts of interest regarding the publication of this paper.

\section{References}

[1] Maclean, J.L., Dawe, D.C., Hardy, B. and Hettel, G.P. (2002) Rice Almanac. 3rd Edition, CABI Publishing, Wallingford (UK), 253.

[2] Tuong, T.P. and Bouman, B.A.M. (2003) Rice Production in Water-Scarce Environments. Water Productivity in Agriculture. Limits and Opportunities for Improvement, 1, 13-42.

[3] Johnson, D.E. and Mortimer, A.M. (2005) Issues for Weed Management in Direct-Seeded Rice and the Development of Decision-Support Frameworks. In: Workshop on Direct-Seeded Rice in the Rice-Wheat System of the Indo-Gangetic Plains. G.B. Pant University, Pantnager, 223.

[4] Choudhury, B.U., Bouman, B.A.M. and Singh, A.K. (2007) Yield and Water Productivity of Rice-Wheat on Raised Beds at New Delhi, India. Field Crops Research, 100, 229-239. https://doi.org/10.1016/j.fcr.2006.07.009

[5] Kreye, C., Bouman, B.A.M., Reversat, G., Fernandez, L., Cruz, C.V., Elazegui, F. and Llorca, L. (2009) Biotic and Abiotic Causes of Yield Failure in Tropical Aerobic Rice. Field Crops Research, 112, 97-106. https://doi.org/10.1016/j.fcr.2009.02.005

[6] Singh, K.P., Jaiswal, R.K., Kumar, N. and Kumar, D. (2006) Biomass of Nematode and Associated Roots: A Determinant of Symptom Production in Root Knot Disease of Rice (Oryza sativa L.). Journal of Phytopathology, 154, 676-682. https://doi.org/10.1111/j.1439-0434.2006.01170.x

[7] Rao, V.P., Venkateswarlu, B., Yadav, B., Rao, A.S., Rao, K.L.N. and Rani, P.P. (2016) Effect of Sub Surface Drip Fertigation on Water Productivity, Nitrogen Use Efficiency and Economics of Aerobic rice. Plant Archives, 16, 855-858.

[8] Nayak, B.R., Pramanik, K., Panigrahy, N., Dash, A.K. and Swain, S.K. (2015) Yield, 
Nitrogen Uptake and Nitrogen Use Efficiency Indices of Aerobic Rice (Oryza sativa L.) under Various Irrigation Regimes and Nitrogen Levels. International Journal of Bio-Resource, Environment and Agricultural Sciences, 1, 8-13.

[9] Dari, B., Sihi, D., Bal, S.K. and Kunwar, S. (2017) Performance of Direct-Seeded Rice under Various Dates of Sowing and Irrigation Regimes in Semi-Arid Region of India. Paddy and Water Environment, 15, 395-401. https://doi.org/10.1007/s10333-016-0557-8

[10] Ali, M.A., Ladha, J.K., Rickman, J. and Lales, J.S. (2007) Nitrogen Dynamics in lowland Rice as Affected by Crop Establishment and Nitrogen Management. Journal of Crop Production, 20, 89-105.

[11] Kumawat, A., Sepat, S., Kumar, D., Singh, S., Jinger, D., Bamboriya, S.D., and Verma, A.K. (2017) Effect of Irrigation Scheduling and Nitrogen Application on Yield, Grain Quality and Soil Microbial Activities in Direct-Seeded Rice. International Journal of Current Microbiology and Applied Sciences, 6, 130-135. https://doi.org/10.20546/ijcmas.2017.606.015

[12] Mandal, K.G., Kundu, D.K., Thakur, A.K., Kannan, K., Brahmanand, P.S. and Kumar, A. (2013) Aerobic Rice Response to Irrigation Regimes and Fertilizer Nitrogen rates. Journal of Food, Agriculture and Environment, 11, 1148-1153.

[13] Gomez, K.A. and Gomez, A.A. (1984) Statistical Procedures for Agricultural Research. 2nd Edition. John Wiley and Sons, New York, 680.

[14] Viets, F.G. (1962) Fertilizers and the Efficient Use of Water. Advances in Agrono$m y$, 14, 223-264. https://doi.org/10.1016/S0065-2113(08)60439-3

[15] Maheswari, J., Bose, J., Sangeetha, S.P., Sanjutha, S. and Priya, R.S. (2008) Irrigation regimes and $\mathrm{N}$ Levels Influence Chlorophyll, Leaf Area Index, Proline and Soluble Protein Content of Aerobic Rice (Oryza sativa L.). International Journal of Agricultural Research, 3, 307-316. https://doi.org/10.3923/ijar.2008.307.316

[16] Rahman, M.T., Islam, M.T. and Islam, M.O. (2002) Effect of Water Stress at Different Growth Stages on Yield and Yield Contributing Characters of Transplanted Aman Rice. Pakistan Journal of Biological Sciences, 5, 169-172. https://doi.org/10.3923/pjbs.2002.169.172

[17] Parihar, S.S. (2004) Influence of Nitrogen and Irrigation Schedule on Yield, Water Use and Economics of Rice in Summer Season. Annual Plant Soil Research, 6, 29-31.

[18] Jadhav, A.S. and Dahiphale, V.V. (2005) Effect of Irrigation and Nitrogen on Yield and Nitrogen Uptake of Basmati Rice in Vertisols. Journal of Maharastra Agricultural University, 30, 368-369.

[19] Devi, G. and Sumathi, V. (2011) Effect of Nitrogen Management on Growth, Yield and Quality of Scented Rice under Aerobic Conditions. Journal Research ANGRAU, 39, 81-83.

[20] Belder, P., Bouman, B.A.M., Spiertz, J.H.J., Peng, S., Castaneda, A.R. and Visperas, R.M. (2005) Crop Performance, Nitrogen and Water Use in Flooded and Aerobic Rice. Plant and Soil, 273, 167-182. https://doi.org/10.1007/s11104-004-7401-4

[21] Shekara, B.G., Nagaraju and Shreedhara, D. (2010) Growth and Yield of Aerobic Rice as Influenced by Different Levels of N, P and K in Cauvery Command Area. Journal of Maharashtra Agricultural Universities, 35, 195-198.

[22] Uddin, S., Sarkar, M.A.R. and Rahman, M.M. (2013) Effect of Nitrogen and Potassium on Yield of Dry Direct Seeded Rice cv. NERICA 1 in Aus Season. International Journal of Agronomy and Plant Production, 4, 69-75. 
[23] Pradhan, A., Thakur, A. and Sonboir, H.L. (2014) Response of Rice Varieties to Different Levels of Nitrogwn under Rainfed Aerobic Ecosystem. Indian Journal of Agronomy, 59, 76-79.

[24] Balasubramanian, R. (2002) Response of Hybrid Rice to Levels and Time of Application of Nitrogen. Indian Journal of Agronomy, 47, 203-204.

[25] Balamani, K., Ramulu, V., Reddy, M.D. and Uma Devi, M. (2012) Effect of Irrigation Methods and Irrigation Schedules on Aerobic Rice. Journal of Research ANGRAU, 40, 84-86.

[26] Narayan, H., Ramachandra, C., Kalyanmurthy, K.N., Mallareddy and Prabhudev, D.S. (2017) Effect of Nitrogen Level and Time of Application on Yield and Water Use Efficiency of Aerobic Rice. International Journal of Agriculture Sciences, 9, 3690-3693.

[27] Reddy, M.M., Padmaja, B., Veeranna, G. and Reddy, D.V.V. (2013) Response of Aerobic Rice to Irrigation Scheduling and Nitrogen Doses under Drip Irrigation. Journal of Research ANGRAU, 41, 144-148. 